\title{
Surface characterization of ash-layered olivine from fluidized bed biomass gasification
}

\author{
Matthias Kuba ${ }^{1,2}$ (1) Katharina Fürsatz ${ }^{1} \cdot$ Daniel Janisch $^{2} \cdot K^{\circ}$ Kouessan Aziaba ${ }^{2} \cdot$ Damian Chlebda $^{3} \cdot$ Joanna Łojewska $^{3}$. \\ Fredrik Forsberg ${ }^{4} \cdot$ Kentaro Umeki $^{5} \cdot$ Hermann Hofbauer ${ }^{2}$
}

Received: 27 April 2020 / Revised: 25 June 2020 / Accepted: 1 July 2020 / Published online: 9 July 2020

(C) The Author(s) 2020

\begin{abstract}
The present study aims to present a comprehensive characterization of the surface of ash-layered olivine bed particles from dual fluidized bed gasification. It is well known from operation experience at industrial gasification plants that the bed material is activated during operation concerning its positive influence on gasification reactions. This is due to the built up of ash layers on the bed material particles; however, the chemical mechanisms are not well understood yet. Olivine samples from long-term operation in an industrial-scale gasification plant were investigated in comparison to fresh unused olivine. Changes of the surface morphology due to Ca-enrichment showed a significant increase of their surface area. Furthermore, the Ca-enrichment on the ash layer surface was distinctively associated to $\mathrm{CaO}$ being present. The presence of $\mathrm{CaO}$ on the surface was proven by adsorption tests of carbon monoxide as model compound. The detailed characterization contributes to a deeper understanding of the surface properties of ash layers and forms the basis for further investigations into their influence on gasification reactions.
\end{abstract}

Keywords Biomass $\cdot$ Gasification $\cdot$ Ash layer formation $\cdot$ Surface characterization

\section{Introduction}

Conversion of biomass into a gaseous secondary energy carrier through steam gasification enables the production of different sustainable end consumer products. Already demonstrated processes based on steam gasification include not only electricity and district heat but also the production of highgrade transportation fuels [1], pure hydrogen [2, 3], synthetic

Matthias Kuba

matthias.kuba@best-research.eu

Katharina Fürsatz

katharina.fuersatz@best-reserach.eu

1 BEST - Bioenergy and Sustainable Technologies GmbH, Inffeldgasse 21b, $8010 \mathrm{Graz}$, Austria

2 Institute of Chemical, Environmental and Bioscience Engineering, TU Wien, Getreidemarkt 9/166, 1060 Vienna, Austria

3 Jagiellonian University, ul. Gronostajowa 2, 30-387 Kraków, Poland

4 Division of Fluid and Experimental Mechanics, Luleå University of Technology, SE-971 87 Luleå, Sweden

5 Division of Energy Science, Luleå University of Technology, SE-971 87 Luleå, Sweden natural gas $[4,5]$, waxes, or synthetic chemicals [6]. Thus, a multitude of measures to approach the strategy to mitigate the increase of global average temperature by reducing the emissions of greenhouse gases can be addressed by steam gasification of biomass $[7,8]$.

A dual fluidized bed (DFB) steam gasification technology was developed at TU Wien [9]. The principle underpinning this process is the separation of endothermic gasification and exothermic combustion. The heat necessary for devolatilization and gasification is provided by circulating the bed material from the combustion to the gasification reactor. The natural mineral olivine is used as bed material [10]. Steam is used as fluidizing agent for the bubbling bed in the gasification reactor. Fast fluidization in the combustion reactor is realized by using air [9].

Biomass ash plays a major role in fluidized bed gasification, since it interacts with the bed material resulting in ash layer formation on the bed particles' surface [11-13]. This ash layer formation has been studied for different types of bed materials [14], such as olivine [15], quartz [16], or Kfeldspar [14, 17], describing the mechanisms underlying the formation of those layers. While ash layer formation is often associated with negative consequences, such as increased agglomeration tendency $[11,18,19]$ or deposit formation [20, 
21], in steam gasification an increase in its catalytic activity leading to an improvement of the product gas quality could be observed [22, 23]. The improvement of the gas quality could be observed in comparison to non-layered, fresh, bed material both in industrial-scale gasification and also in lab-scale studies on isolated single reactions [24]. The increase in catalytic activity toward gasification reactions was loosely associated to an enrichment of ash components on the particle's surface, mainly calcium [24, 25] and potassium [26].

Through interaction between the fuel ash and bed particles, the surface of olivine becomes covered with an ash layer and the initial surface is no longer available for gaseous reactants. The presence of different ash components has been suggested, such as calcium enrichment on the surface [17, 22, 23, 27], which has a positive impact on the catalytic activity of the bed material. Detailed characterization of the ash layer surface has yet to be conducted to get a better understanding of how the ash components in the ash layer influence gasification.

Therefore, the present study aims to present a comprehensive surface characterization of the ash layer, which is formed through interaction with biomass ash in the fluidized bed reactor. The characterization aims to describe morphological changes of the particle surface associated with the ash layer formation. Furthermore, the study should identify ash components on the surface through adsorption techniques. The so gained more detailed information of the surface properties of ash layers shall form a basis for a deeper understanding of their role in gasification.

\section{Materials and methods}

\subsection{Description of the industrial DFB gasification plant in Senden}

Bed material samples for used layered olivine were taken from the industrial-scale DFB gasification plant in Senden, Germany. The power plant has a fuel power of $15 \mathrm{MW}_{\text {th }}$ and generates electricity of about $5.1 \mathrm{MW}_{\mathrm{el}}$ by means of two gas engines and an organic rankine cycle (ORC). Furthermore, the power plant produces district heat of 6.4 $\mathrm{MW}_{\text {th. }}$.

The biomass fuel used is typically referred to as logging residues, which include cut-off root ends, as well as tops and branches and was described in detail in previous studies [28].

The fuel is collected in four storage silos on-site and is taken alternating from the different silos to be fed into the biomass dryer. Therefore, an increased homogenization of the fuel is achieved. A simplified flow sheet of the process underlying the power plant was provided by Kuba et al. [29]

The fuel is transported into the gasification reactor of the DFB system by a screw conveyor. It is fed directly into the bubbling fluidized bed and is therefore immediately in contact with the bed material. As currently in all industrial-scale DFB gasification plants, the mineral olivine is used as bed material. The bed material has two major roles in the process. First, it acts as heat carrier between the combustion and the gasification reactor and second, it acts as catalyst for the gasification reactions to improve the quality of the product gas. The bubbling bed in the gasification reactor is typically kept at a temperature of $850^{\circ} \mathrm{C}$. Steam is used as fluidization medium and gasifying agent, uniform mixing of bed material, and fuel was ensured through evenly distributed fluidization nozzles across the fluidized bed diameter [30]. Part of the char from the gasification reactor is transported together with bed material to the combustion reactor via a chute. In the combustion reactor, char is burned in a fast fluidized bed at temperatures of up to $930{ }^{\circ} \mathrm{C}$ using air as fluidization medium. As a result, the bed material is heated up and is then transported back to the gasification reactor after being separated from the flue gas via a cyclone. The bed material passes through a syphon which is fluidized with steam, so that no flue gas can enter the gasification reactor.

Complete oxidation of the flue gas is ensured in a postcombustion chamber, where air is added. Part of the particles which are entrained with the flue gas and not separated in the cyclone is recirculated to the DFB reactor system as coarse ash. After gas cleaning, the product gas is brought to gas engines for the generation of electricity and heat.

Table 1 shows the typical composition of the fuel ash determined from fuel samples collected during the steady state operation, in which sampling of bed particles was conducted.

\subsection{Sampling of bed particles}

The sampling itself was performed at the bottom of the combustion reactor, shown in Fig. 1. Used layered olivine is regularly discharged together with impurities from the biomass fuels, such as larger stones, which cannot be fluidized. Thus, the discharged inorganic fraction from the bottom of the combustion reactor is sieved with a $1 \mathrm{~mm}$ sieve to obtain the used layered olivine particles $(<1 \mathrm{~mm})$.

Fresh olivine is brought into the system regularly during steady state operation to compensate bed material loss due to abrasion in the fluidized bed and discharge, which is described above. Therefore, the exact particle age of the used, layered olivine sample cannot be distinctively determined. However, the sample corresponds to the activated bed in steady state operation of industrial-scale dual fluidized bed gasification plants. Therefore, this sample is of the highest relevance for this study.

Samples of fresh olivine were taken from the bed material storage on-site directly after it being delivered. Fresh olivine is not further described here, as it is a known mineral with known properties and characteristics. Further information can be found in literature [31]. 
Table 1 Elemental composition (expressed as oxides) of fuel ash identified with XRF analysis

\begin{tabular}{ll}
\hline Measured comp. & Mass fraction, given in $\%$ \\
\hline $\mathrm{SnO}$ & $0.02 \%$ \\
$\mathrm{ZrO}_{2}$ & $0.02 \%$ \\
$\mathrm{SrO}$ & $0.22 \%$ \\
$\mathrm{ZnO}$ & $0.13 \%$ \\
$\mathrm{CuO}$ & $0.02 \%$ \\
$\mathrm{NiO}$ & $0.01 \%$ \\
$\mathrm{Fe}_{2} \mathrm{O}_{3}$ & $0.70 \%$ \\
$\mathrm{MnO}_{\mathrm{Cr}}$ & $0.18 \%$ \\
$\mathrm{Cr}_{2} \mathrm{O}_{3}$ & $0.02 \%$ \\
$\mathrm{TiO}_{2}$ & $0.16 \%$ \\
$\mathrm{CaO}$ & $55.61 \%$ \\
$\mathrm{~K}_{2} \mathrm{O}$ & $12.57 \%$ \\
$\mathrm{Cl}$ & $0.06 \%$ \\
$\mathrm{SO}_{3}$ & $2.87 \%$ \\
$\mathrm{P}_{2} \mathrm{O}_{5}$ & $4.85 \%$ \\
$\mathrm{SiO}_{2}$ & $13.42 \%$ \\
$\mathrm{Al}_{2} \mathrm{O}_{3}$ & $3.26 \%$ \\
$\mathrm{MgO}$ & $5.04 \%$ \\
$\mathrm{Na}_{2} \mathrm{O}$ & $0.83 \%$ \\
$\mathrm{Sum}$ & $100.00 \%$ \\
\hline
\end{tabular}

\subsection{XRD analysis}

$\mathrm{X}$-ray diffraction (XRD) data collections were performed with a Bruker $\mathrm{d} 8$ Advance instrument in $\theta-\theta$ mode with an optical configuration consisting of $\mathrm{Cu} \mathrm{K} \alpha$ radiation, and a Vantec-1 detector. Continuous scans were made; therefore, the total data collection time for each sample was more than $6 \mathrm{~h}$. The PDF-2 database with Bruker software was used to gain initial qualitative identifications. The data were then further analyzed by the Rietveld technique and structure data from the Inorganic Crystal Structure Database (ICSD). As a result, semi-quantitative information on the present crystalline phases was gained.

\subsection{ESEM/EDS analysis}

Samples were used in their original form for surface measurements. Samples of bed material were positioned on a sample holder and investigated using an environmental scanning electron microscope (ESEM). The analysis was used to determine the morphology of the bed particle surface. Therefore, the ESEM analysis included in the present study was focused on both measuring the composition of the ash-layer and also to interpret the morphological changes due to ash layer formation.

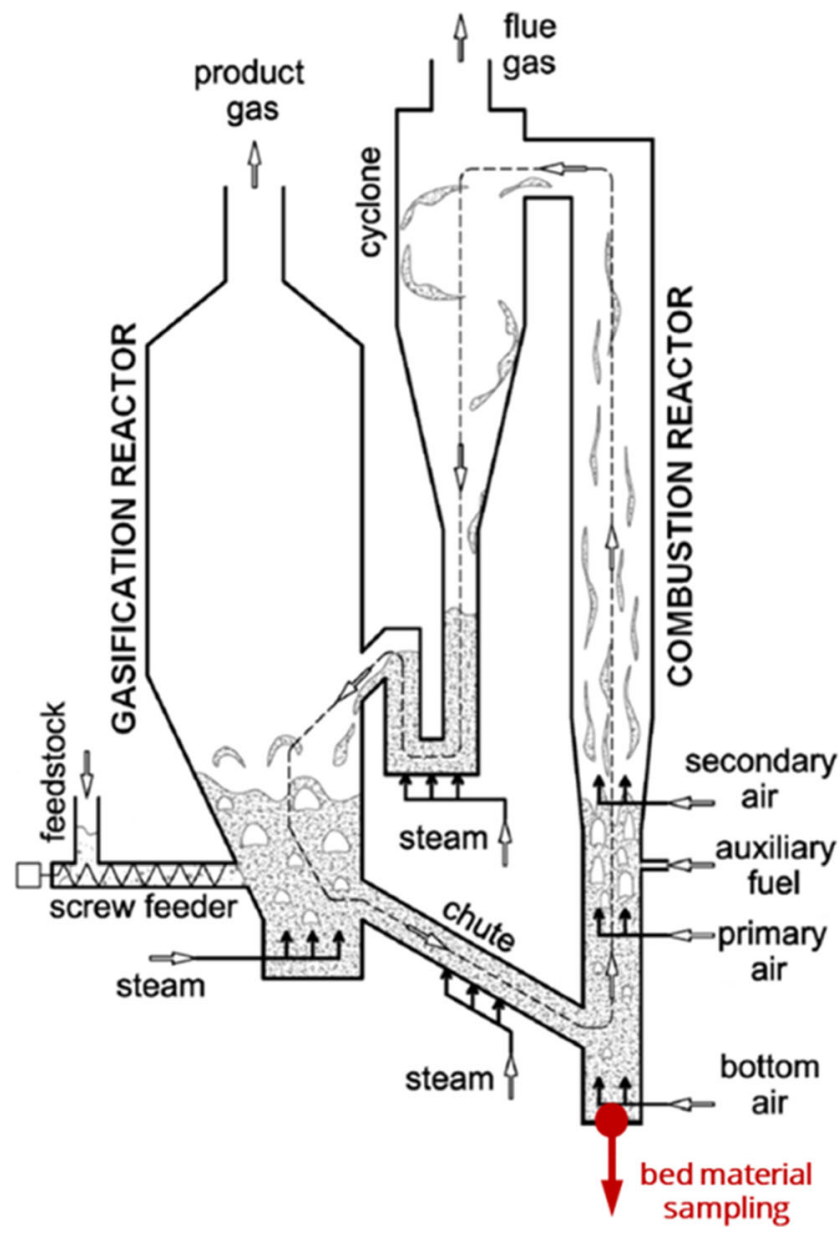

Fig. 1 Scheme of the DFB gasifier showing the sampling point of bed material at the bottom of the combustion reactor

Additionally, samples were mounted in epoxy, grinded, and polished to obtain cross-sections of the particles for further analysis. The grinding was carried out using dry grinding paper, so that solubility of certain ash components, such as alkali, could be excluded.

The composition of the ash layer was analyzed using energy dispersive X-ray spectroscopy (EDS). For that, between 5 and 7 point analyses were performed on each particle within the sample on different areas of the ash layer. Overall, over 200 particles were investigated this way. Values presented in this study are mean values received for multiple measurements of comparable areas, e.g., referred to as the outermost layer or the outer layer. Quantification of EDS analysis is not included in this study, only qualitative assessments will be discussed.

\subsection{X-ray microtomography analyses}

Macropore structures of fresh and used olivine particles were analyzed with X-ray microtomography $(\mathrm{XMT}, \mu \mathrm{CT})$. During an XMT scan, a large number of X-ray projection images are captured at equal angles as the sample makes one full rotation. 
Based on the projection data, the full 3D-microstructure of the sample is reconstructed using tomographic software.

Here, a group of particles was scanned using a Zeiss Xradia 510 Versa (Carl Zeiss X-ray Microscopy, Pleasanton, CA, USA) with a $\times 20$ objective, resulting in a field of view of $0.85 \mathrm{~mm}$ and voxel size of $0.85 \mu \mathrm{m}$. The scanning was carried out with an X-ray tube voltage of $60 \mathrm{kV}$ and an output effect of $5 \mathrm{~W}$. During each scan, 1601 projection images were acquired with an exposure time of $16 \mathrm{~s}$ each, which resulted in a total scan time of approximately $9 \mathrm{~h}$ (per sample). The tomographic reconstruction was carried out using Zeiss Scout-andScan Reconstructor software, and the visualization was done with Dragonfly software (ORS).

\subsection{BET analysis}

Brunauer-Emmet-Teller (BET) surface area analysis was performed twice for each sample with two different analysis setups to verify the results. This procedure was chosen based on the fact that the surface areas were comparably small for the determination of the surface area with BET analysis.

The first analysis was performed with nitrogen sorption at - $196{ }^{\circ} \mathrm{C}$ which was carried out using a 3Flex v1.00 (Micromeritics) automated gas adsorption system. Prior to the analysis, samples were degassed under vacuum at $350{ }^{\circ} \mathrm{C}$ for $24 \mathrm{~h}$. Sample weights amounted to $300 \mathrm{mg}$.

The second analysis was conducted with a Micromeritics ASAP 2020 V4.00 and nitrogen sorption also at $-196{ }^{\circ} \mathrm{C}$. Prior to analysis, the samples were degassed under vacuum at $350{ }^{\circ} \mathrm{C}$ for $8 \mathrm{~h}$. Analyzed sample weights amounted to around $1000 \mathrm{mg}$.

Since the results of the two procedure steps matched accurately, the reliability of the measured surface areas could be confirmed.

\subsection{FT-IR analysis}

Fourier-transform infrared spectroscopy (FT-IR) spectra were recorded in transmission using a Bruker Vertex 70 spectrometer with an MCT detector by averaging 128 scans.

Scanning in mid-IR range was performed using the THERMO/Nicolet 8700 spectrometer equipped with a liquid nitrogen-cooled mercury cadmium telluride (MCT) detector. The samples were placed without preparation in a Praying Mantis High-Temperature Reaction Chamber (Harrick Scientific Co., Ossining, NY) with ZnSe windows. The gas flow for adsorption experiments was set to

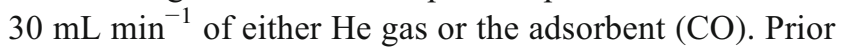
to analysis, the sample was annealed at $500{ }^{\circ} \mathrm{C}$ in $\mathrm{He}$ atmosphere. The instrument was controlled by OPUS v 8.0 software.

\subsection{Raman spectroscopy}

Raman spectroscopy was performed at a LabRAM HR800 confocal Raman microscope (Horiba Jobinn Yvonne, France). Possible employed laser lines: He-Ne (633 nm), diode $(532 \mathrm{~nm})$, and $\mathrm{HeCd}(325 \mathrm{~nm})$; however, the red laser $(532 \mathrm{~nm})$ with $50 \mathrm{~mW}$ power yielded the best results and was almost always used. The catalyst and reference samples were loaded without preparation in a reactor cell LinkamCCR1000 (Scientific Instruments Ltd., Waterfield, Surrey, England), fitted with quartz windows. Raman heating experiments were conducted with a $30 \mathrm{~mL} / \mathrm{min}$ flow of He gas in a high temperature reaction chamber (Harrick Scientific Co., Ossining, NY) with $\mathrm{SiO}_{2}$ windows. The laser signal was calibrated at a pure silica specimen to $520 \mathrm{~cm}^{-1}$ Raman shift.

\section{Results and discussion}

\subsection{Surface morphology changes through ash layer formation}

Figure 2 shows 3D (left) and cross-sectional images (right) of fresh and ash-layered olivine from the XMT analyses. In the 3-D images, lighter color indicates regions with higher density, and the darker color means regions with lower density. For the $3 \mathrm{D}$ images, the color ranges were adjusted to make background signals transparent while the two images have the same color ranges.

A difference in the density could be observed. The color scales in these images are adjusted to make the regions with the same density appear as the same color. Ash-layered olivine is showing brighter color, which means an increase in local particle density. This can be caused by structural changes in the layer originating from the layer formation mechanism, which is based on a substitution reaction, where $\mathrm{Ca}^{2+}$ ions are incorporated into the crystal structure of olivine, while $\mathrm{Fe}^{2+}$ and $\mathrm{Mg}^{2+}$ ions are excluded from the crystal structure [15]. Furthermore, other ash components, present to a minor extent in comparison to $\mathrm{CaO}$, such as $\mathrm{K}$ or $\mathrm{Si}$, can lead to sintering on the surface further increasing the density of the layer. Moreover, fresh olivine particles have relatively uniform density distributions, although they contain some highdensity regions due to the inhomogeneity of particles. On the other hand, ash-layered olivine particles have very highdensity regions in each particle.

Finally, the surface layers of the particle shows higher density than original particles. Moreover, the high-density surface layers have rough surfaces compared to fresh olivine particles, which may be regarded as porous structure.

When comparing fresh with used layered olivine, a change in morphology could be observed on the surface. Figure 3 (left) shows the surface of a fresh olivine particle, which was 
Fig. 2 3D (left) and crosssectional (right) images of fresh olivine (top) and ash-layered olivine (bottom) from X-ray microtomography
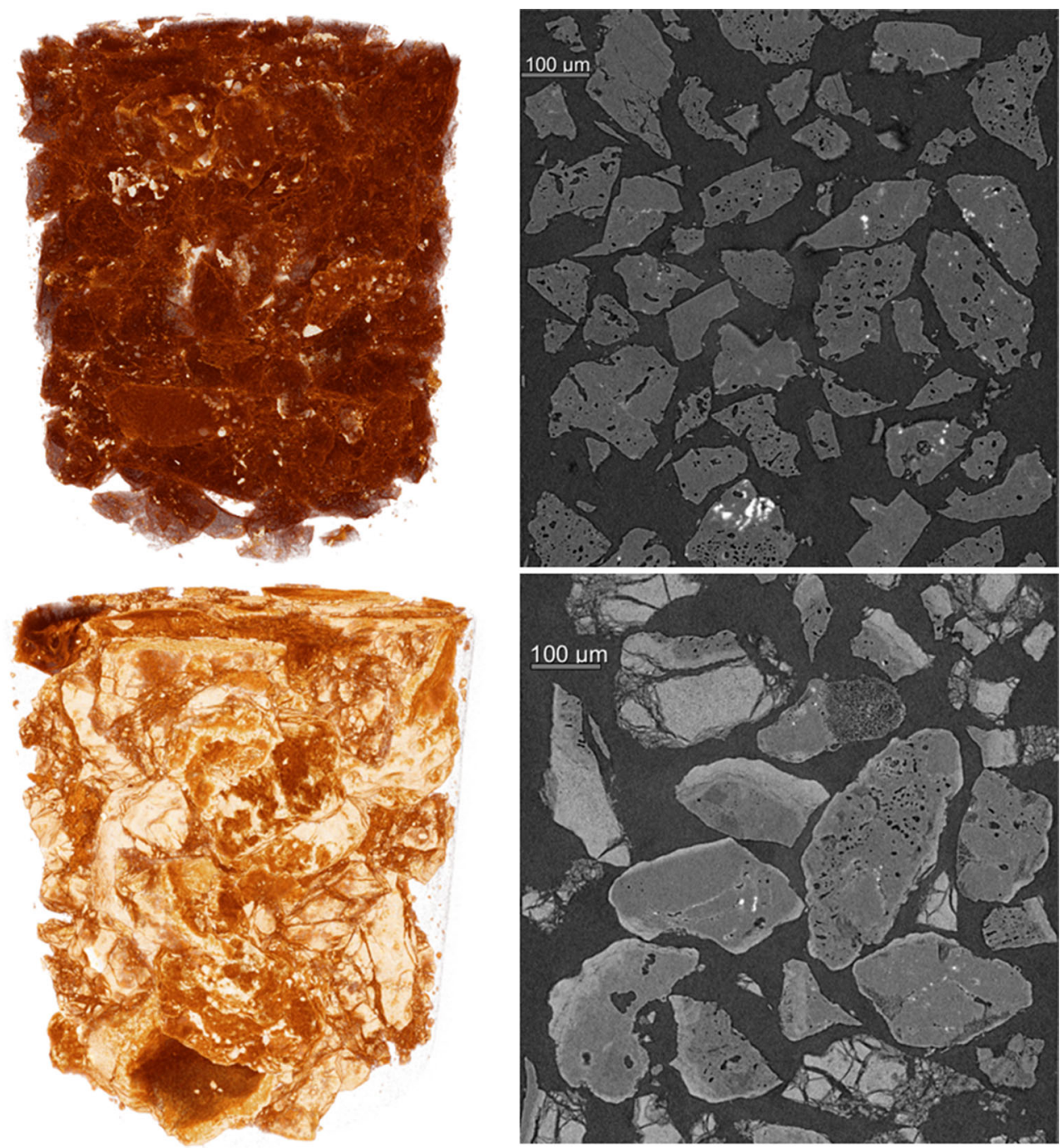

characterized by well-organized crystalline structures. In contrast, Fig. 3 (right) shows an increased surface irregularity for used layered olivine due to the interaction with biomass ash and subsequent ash layer formation.

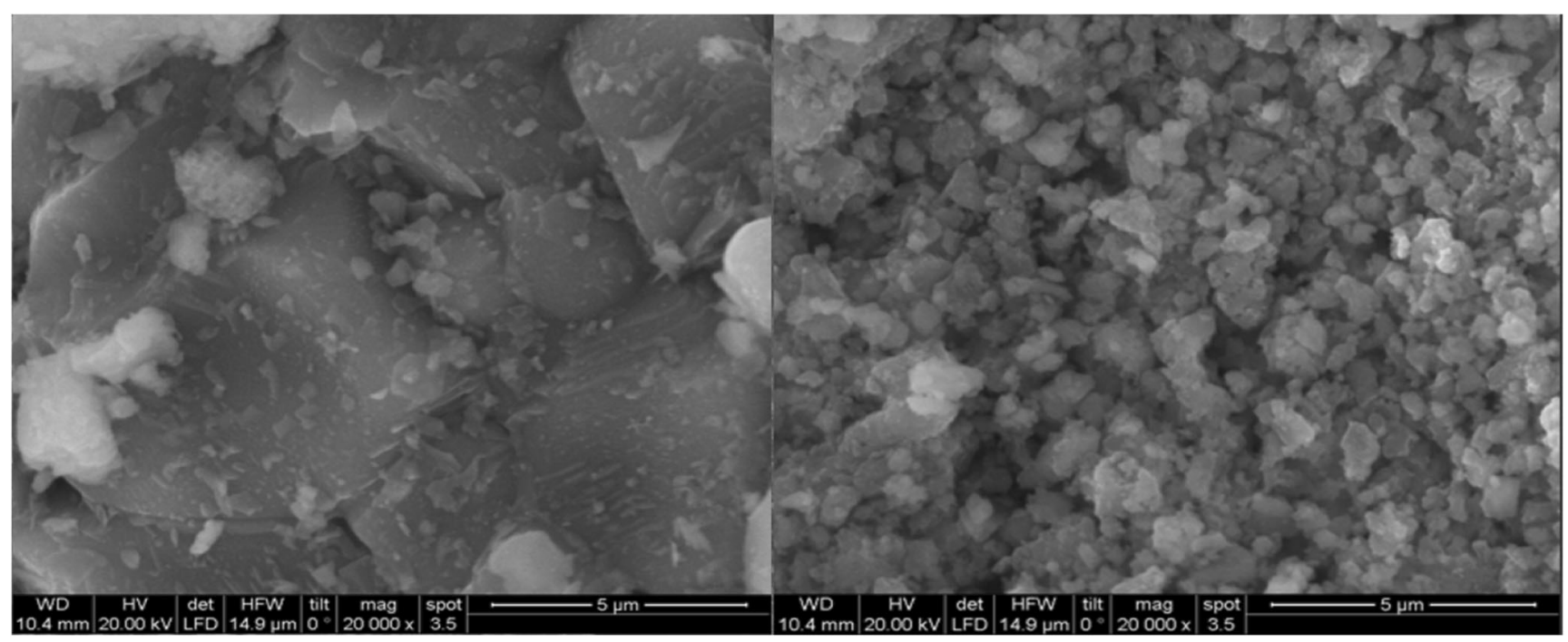

Fig. 3 ESEM images of the surface of fresh olivine (left) and ash layered olivine (right) 
In agreement with the observed morphology of the particle surface, BET analysis showed an increase of the surface area for used layered olivine. While a surface area of $0.4 \mathrm{~m}^{2} \mathrm{~g}^{-1}$ was measured for fresh olivine, the surface area of used layered olivine was as high as $4.6 \mathrm{~m}^{2} \mathrm{~g}^{-1}$. Compared to industrial catalysts with surface areas above $100 \mathrm{~m}^{2} \mathrm{~g}^{-1}$, the surface area of ash-layered olivine is still low.

The more clearly defined, three-dimensional, landscape on the particle surface shows the change of morphology through ash layer formation. Deposited ash particles forming the outer particle layer - compared to the inner reaction layer described in Kuba et al. [15] — redefines the newly developed surface.

Table 2 shows measurements from the used layered olivine sample which is investigated in this study. X-ray diffraction (XRD) are bulk measurements and therefore show the entirety of the sample; thus, both the olivine particle itself and also the formed ash layer. In comparison to used layered olivine, fresh olivine from the present study comprises almost exclusively of Foresterite $\left(\mathrm{Mg}_{2} \mathrm{SiO}_{4}\right)$ and to a minor extent, quartz and hematite, which were detectable but not quantifiable. Fayalite $\left(\mathrm{Fe}_{2} \mathrm{SiO}_{4}\right)$ could not be detected. All other components shown in the table do not apply to fresh olivine.

\subsection{Characterization of surface components}

Analysis using ESEM/EDS shows initial layer formation resulting in thin ash layers on the surface associated with Ca-enrichment, as described before in previous publications [12]. Initial layer formation is characterized by only partial coverage of the particle surface, thus surface analysis still dominantly leads to observation of the properties of fresh olivine. Initial layer formation has been described as deposition of ash-derived components with subsequent substitution of

Table 2 XRD analysis of ash layered olivine, adapted from [28]

\begin{tabular}{lll}
\hline XRD & & \\
\hline Measured comp. & & Mass fraction, given in \% \\
\hline Forsterite & $\mathrm{Mg}_{2} \mathrm{SiO}_{4}$ & 76.5 \\
Quartz & $\mathrm{SiO}_{2}$ & 3 \\
Lime & $\mathrm{CaO}$ & 3.5 \\
Calcite & $\mathrm{CaCO}_{3}$ & 1.5 \\
Larnite & $\mathrm{Ca}_{2} \mathrm{SiO}_{4}$ & 4 \\
Merwinite & $\mathrm{Ca}_{3} \mathrm{Mg}_{\left(\mathrm{SiO}_{4}\right)_{2}}$ & 2.5 \\
Bredigite & $\mathrm{Ca}_{7} \mathrm{Mg}_{\left(\mathrm{SiO}_{4}\right)_{4}}$ & 1.5 \\
Archanite & $\mathrm{K}_{2} \mathrm{SO}_{4}$ & 1.5 \\
Periclase & $\mathrm{MgO}_{\text {Kalsilite }}$ & 3 \\
& $\mathrm{KAlSiO}_{4}$ & 1 \\
Hematite & $\mathrm{K}_{2} \mathrm{MgSiO}_{4}$ & 1 \\
\hline
\end{tabular}

$\mathrm{Fe}^{2+}$ and $\mathrm{Mg}^{2+}$ from the crystal structure with $\mathrm{Ca}^{2+}$ leading to an incorporation of $\mathrm{Ca}$. Initial layer formation is shown in Fig. 4 from cross-sections of bed particles. During initial layer formation, no distinction between inner and outer layers can yet be made.[15, 32]. Outer layer formation has been described as ash deposition on the surface resulting in an accumulation of mainly $\mathrm{Ca}$ on the surface. The surface of already layered particles shows a slight increase of $\mathrm{Ca}$, which rises over time.

The layer formation mechanism described in previous work [15] has direct consequences for the surface characterization. While EDS measurements show the presence of $\mathrm{Ca}$ on the surface, the substitution reaction leads to a Mg-enrichment further inside the ash layer, which results in crack formation inside the ash layer. Layer breakage then leads to exposure of Mg-rich surface areas. This Mg-enrichment, then measured at the particle's surface, originates from the olivine's crystal structure and has been pushed out through the incorporation of $\mathrm{Ca}^{2+}$ ions into the crystal structure. However, it should be stated here that $\mathrm{Ca}$ is still the dominant ash component on the surface, shown by measurements from Kuba et al. [15].

Additionally, EDS measurements also show Mg-enrichment, most likely in the form of MgO-particles, at the outermost surface of the outer ash layer, even before breakage of the layer, see Fig. 5. This is most likely originated from deposition of ash-derived $\mathrm{MgO}$ particles. This $\mathrm{Mg}$-enrichment in the outermost region of the ash layer is difficult to measure, as it is irregular regarding its presence on the surface and comparably thin in comparison to the total ash layer.

In summary, ESEM/EDS analysis suggests $\mathrm{Ca}$ and $\mathrm{Mg}$ to be the two most dominant ash-derived components to be present on the surface of the ash layer. Other ash components can also be present on the surface to a lesser extent as a result of deposition of ash components.

The identification of ash-derived components suggested by initial ESEM analysis was conducted by comparing fresh and ash-layered olivine samples to model ash compounds such as pure $\mathrm{MgO}$ and $\mathrm{CaO}$ in FT-IR analysis.

Figure 6 shows the results from vibrational spectroscopy performed with FT-IR. Used layered olivine shows significant peaks differentiating it from fresh olivine. The broad band around $1480 \mathrm{~cm}^{-1}$ corresponds together with the peak at $875 \mathrm{~cm}^{-1}$ to $\mathrm{C}-\mathrm{O}$ elongation modes of carbonates. The broad $1480 \mathrm{~cm}^{-1}$ band also appears for pure $\mathrm{CaO}$, which strongly hints toward the presence of $\mathrm{CaO}$ on the surface of used layered olivine.

To prove the presence of $\mathrm{CaO}$ on the surface of the ash layer, the adsorption of carbon monoxide on $\mathrm{CaO}$ was investigated using FT-IR.

Figure 7 presents the results obtained for the adsorption of carbon monoxide on pure $\mathrm{CaO}$. Two prominent peaks at 2170 and $2120 \mathrm{~cm}^{-1}$ during the adsorption belong to gas phase $\mathrm{CO}$. Adsorbed species of $\mathrm{CO}$ on a transition metal would produce a 

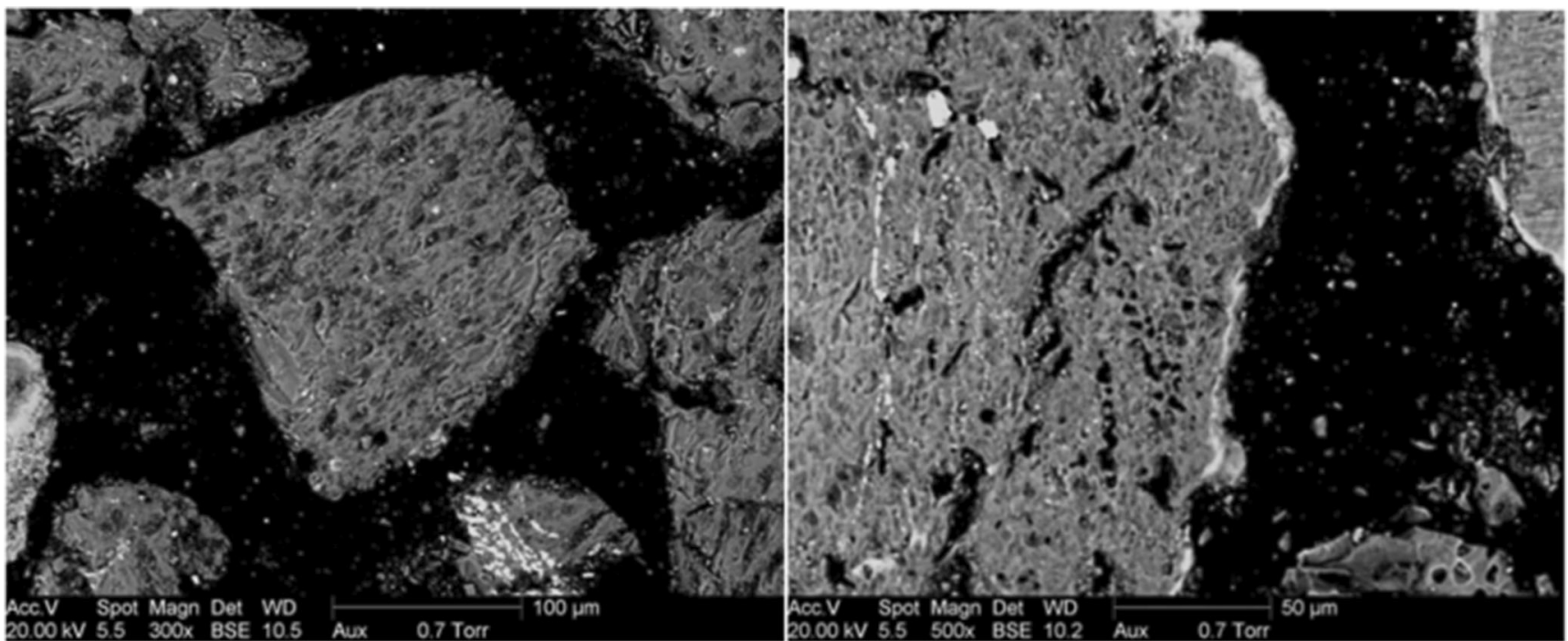

Fig. 4 Cross-section ESEM images of fresh olivine (left) and initial layer formation (right)

signal just below $2100 \mathrm{~cm}^{-1}$. However, a peak at $1565 \mathrm{~cm}^{-1}$ is observed already during adsorption at low temperatures. Further, $1565 \mathrm{~cm}^{-1}$ ranges in the regime of C-O stretching modes of $\mathrm{CO}_{2}{ }^{-2}$. The distinction between formate and carbonate signals is not distinctive. However, $1565 \mathrm{~cm}^{-1}$ could be allocated to carbonate that decreases with elevated temperatures and the smaller peak at $1338 \mathrm{~cm}^{-1}$ to formate.

The adsorption of $\mathrm{CO}$ on ash-layered olivine is not very pronounced, which is recognizable by comparably high noise levels in Fig. 8. Nevertheless, a clearly measureable peak at $1365 \mathrm{~cm}^{-1}$ remained after evacuating the IR chamber. This peak could be attributed to formate, as already observed above for the $\mathrm{CO}$ adsorption on $\mathrm{CaO}$. A second peak emerging at $1595 \mathrm{~cm}^{-1}$ corresponds also to C-O of formate groups by reaction with $\mathrm{CaO}$. In addition, a sharp peak at $2044 \mathrm{~cm}^{-1}$ was detected that corresponds to chemisorbed $\mathrm{CO}$ on iron. A broad peak around $1923 \mathrm{~cm}^{-1}$ was also measured but could not be distinctively assigned.

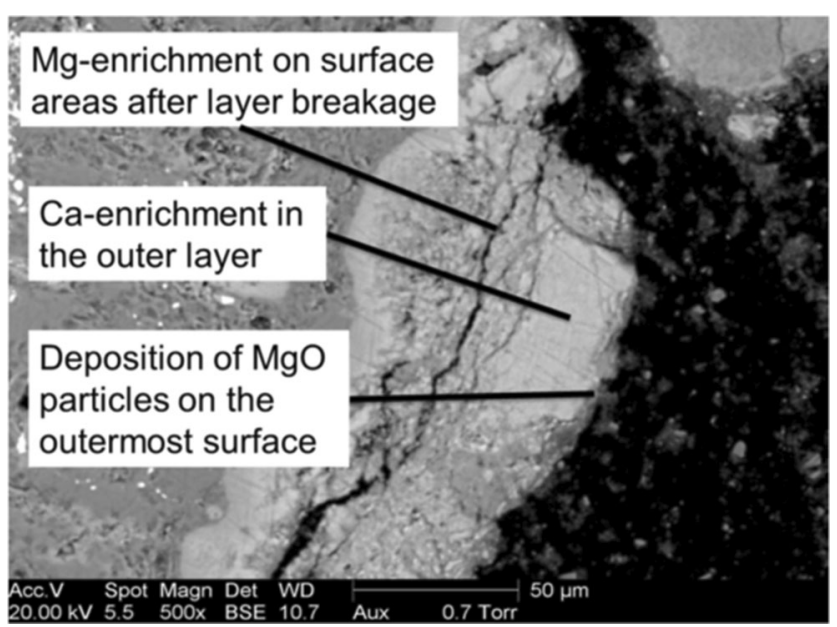

Fig. 5 Mg-enrichment along cracks and on the outermost surface of ash layered olivine
Figure 9 shows the Raman spectra of fresh and used, layered, olivine. For both samples, the characteristic peaks at 856 and $825 \mathrm{~cm}^{-1}$ are associated with foresterite $\left(\mathrm{Mg}_{2} \mathrm{SiO}_{4}\right)$. The peak at $1310 \mathrm{~cm}^{-1}$ corresponds to $\mathrm{Fe}_{2} \mathrm{O}_{3}$; it is noteworthy to state that the peak for used, layered, olivine is significantly more pronounced. This might be caused by the mobility of iron in the crystal structure of olivine during layer formation $[13,15] . \mathrm{Fe}^{2+}$ ions tend to be more mobile during layer formation, when it comes to incorporation of $\mathrm{Ca}^{2+}$ ions through substition with either $\mathrm{Fe}^{2+}$ or $\mathrm{Mg}^{2+}$. Through the higher mobility of iron, an enrichment of iron can be observed in the initial phase of ash layer formation. As this is associated with the initial ash layer formation step, this seem to be only observable for particles with thin ash layers. Figure 10 shows areas of Fe-enrichment near the particle surface, which are visible as brighter spots in the ESEM images. The Raman

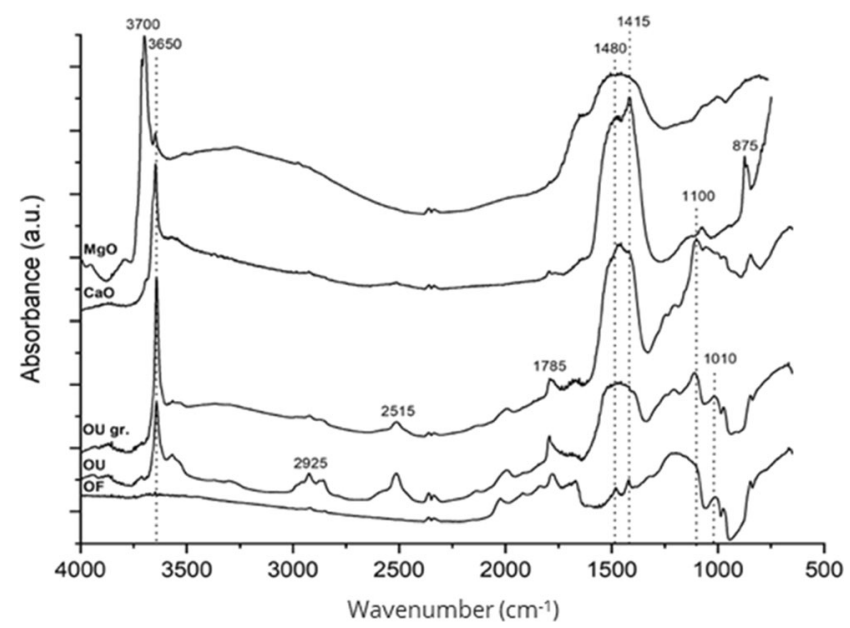

Fig. 6 FTIR-spectra of fresh olivine (OF), ash-layered used olivine (OU) used, and finely ground ash-layered used olivine (OU gr.) in comparison to pure $\mathrm{CaO}$ and $\mathrm{MgO}$ (DRIFTS) 


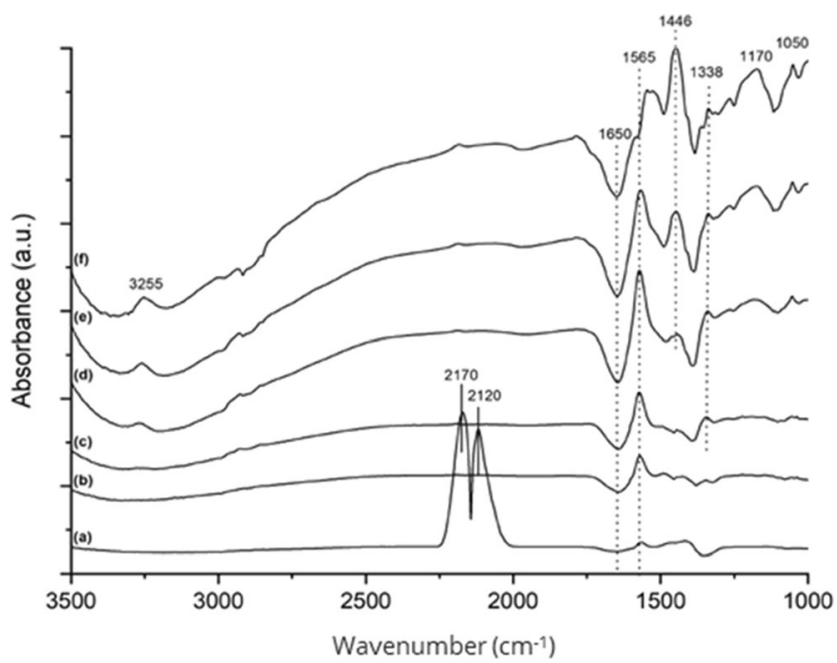

Fig. 7 FTIR-spectra of $\mathrm{CO}$ adsorption on $\mathrm{CaO}$ (Transmission mode): a subtraction result $\mathrm{CaO}$ during $\mathrm{CO}$ adsorption 500 mbar ambient temperature, $\mathbf{b}$ after $\mathrm{CO}$ adsorption vacuum ambient temperature, $\mathbf{c}$ $100{ }^{\circ} \mathrm{C}, \mathbf{d ~} 200{ }^{\circ} \mathrm{C}$, e $300{ }^{\circ} \mathrm{C}$, and f $400{ }^{\circ} \mathrm{C}$

analysis seems to be in line with observations from ESEM/ EDS analysis.

Ash layer formation could be identified in the area of 650 $712 \mathrm{~cm}^{-1}$, where at around $650 \mathrm{~cm}^{-1} \mathrm{CaO}$ can be assigned and $712 \mathrm{~cm}^{-1}$ could correspond to $\mathrm{CaCO}_{3}$. Since those two peaks are close to each other, a differentation between them is not possible due to overlapping of the peaks.

The surface measurement techniques, FT-IR, CO adsorption, and Raman, show several important findings regarding the caracterisation of the ash layer surface on olivine. Measurements on the surface showed that it is a heterogeous area comprised of different ash components. $\mathrm{CaO}$ was clearly identfied. However, due to the comparably small surface areas on ash-layered olivine particles of only about $4.6 \mathrm{~m}^{2} / \mathrm{g}$, the CO

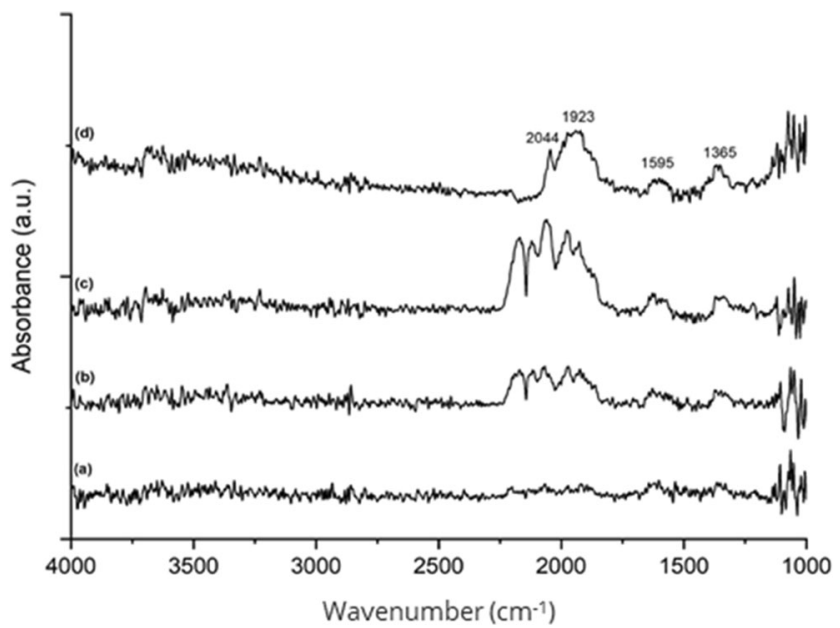

Fig. 8 FTIR-spectra of $\mathrm{CO}$ adsorption on ash-layered used olivine (transmission mode). a Subtraction result during $\mathrm{CO}$ adsorption 10 mbar ambient temperature. b Subtraction result during $\mathrm{CO}$ adsorption 50 mbar a.t. c Subtraction result during CO adsorption 100 mbar a.t.. d After adsorption and vacuum

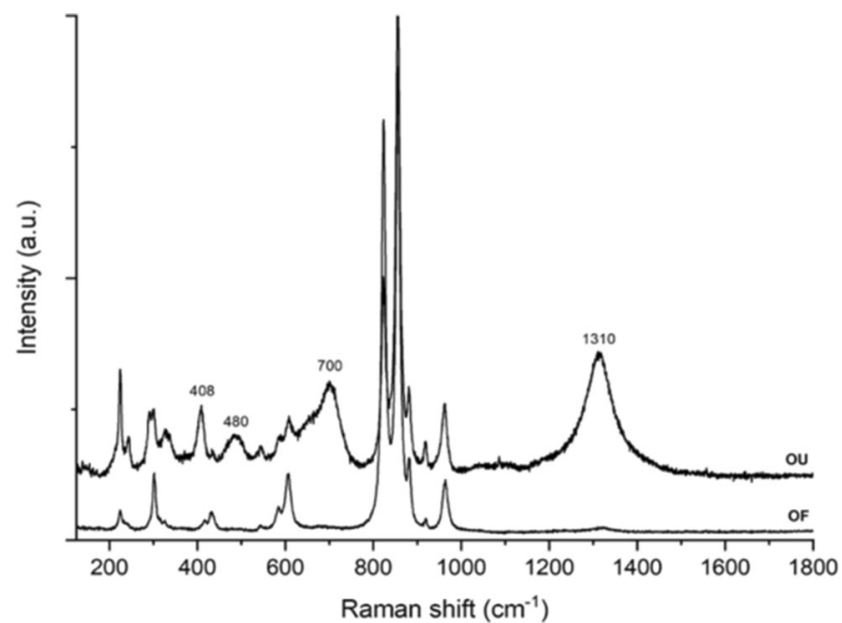

Fig. 9 Raman spectra of used, layered, olivine (OU) and fresh olivine (OF)

adsorption measurements were overshadowed by background noise. The presence of $\mathrm{CaO}$ could thus be observed; the presence of other ash-derived components is not excluded from this assessment. This is also due to the fact that ash-derived $\mathrm{MgO}$, of which the presence is suggested by ESEM/EDS analysis, is difficult to conclusively distiguish from the $\mathrm{Mg}$ content of the olivine particle itself.

\section{Conclusions}

Through a variety of different experimental and analytical investigations, a comprehensive surface characterization of ash-layered olivine has been conducted. $\mathrm{CaO}$ could be identified to play a dominant role on the surface of ash layered olivine. The following main conclusions can be drawn:

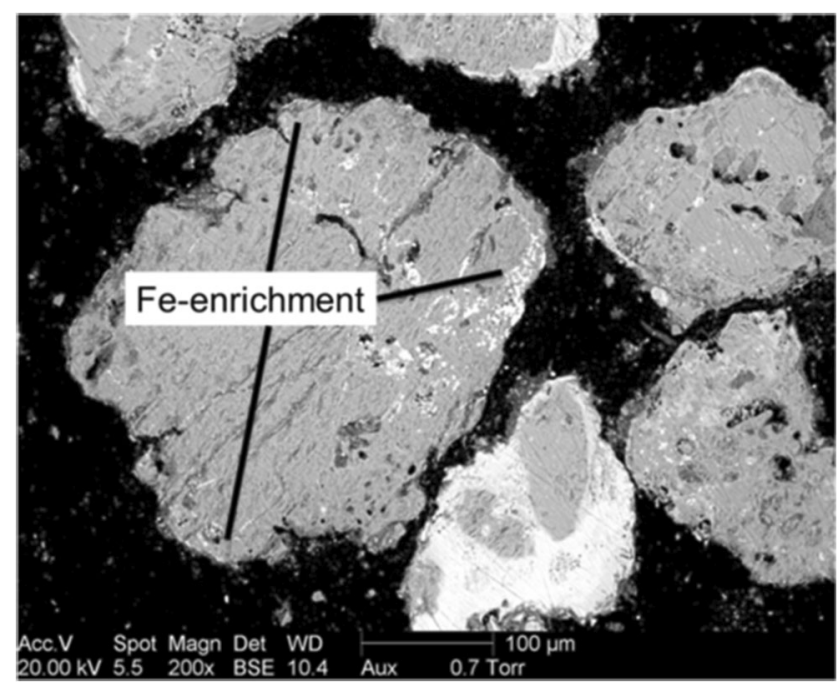

Fig. 10 Brighter spots near the surface correspond to Fe-enrichment 
- Changes of the particle surface due to interaction of the bed material with the biomass ash were investigated. An increase of BET-surface area by a factor of ten could be assigned to ash layer formation, which leads to a more pronounced three-dimensional landscape on the surface.

- The microtomography showed the increase in density of olivine particles. In addition, the formed ash layer has a rough surface, which can increase the effective surface area of $\mathrm{CaO}$ active sites.

- The presence of $\mathrm{CaO}$ on the ash layer surface could be distinctively proven. $\mathrm{CaO}$ could be identified using different techniques such as XRD, ESEM/EDS, FT-IR, and Raman analysis, as well as adsorption tests using $\mathrm{CO}$ as model compound.

- Deposition of ash-derived $\mathrm{MgO}$ on the outermost region of the ash layer could be identified with ESEM/EDS. However, due to the comparably small surface are, FTIR and Raman measurements as well as adsorption tests using $\mathrm{CO}$ as model compound could not conclusively identify $\mathrm{MgO}$ on the surface. This shows the limits of certain measurement techniques on the comparably small surface areas of ash layered bed particles.

This characterization of the ash layer surface forms the basis for further investigations into the mechanisms underlying the influence of ash layer formation on the product gas quality in gasification, which was observed as a result of the presence of ash-derived components on the surface.

Acknowledgments This study was carried out within the BEST GmbH project C-20-060. BEST GmbH is funded within the Austrian COMET program, which is managed by the Austrian Research Promotion Agency (FFG) and promoted by the Federal Government of Austria as well as the federal states of Vienna, Lower Austria, and Styria.

Funding information Open access funding provided by TU Wien (TUW).

Open Access This article is licensed under a Creative Commons Attribution 4.0 International License, which permits use, sharing, adaptation, distribution and reproduction in any medium or format, as long as you give appropriate credit to the original author(s) and the source, provide a link to the Creative Commons licence, and indicate if changes were made. The images or other third party material in this article are included in the article's Creative Commons licence, unless indicated otherwise in a credit line to the material. If material is not included in the article's Creative Commons licence and your intended use is not permitted by statutory regulation or exceeds the permitted use, you will need to obtain permission directly from the copyright holder. To view a copy of this licence, visit http://creativecommons.org/licenses/by/4.0/.

\section{References}

1. Sauciuc A, Abosteif Z, Weber G, Potetz A, Rauch R, Hofbauer H, Schaub G, Dumitrescu L (2012) Influence of operating conditions on the performance of biomass-based Fischer-Tropsch synthesis. Biomass Convers Biorefinery 2:253-263

2. Fail S, Diaz N, Benedikt F, Kraussler M, Hinteregger J, Bosch K, Hackel M, Rauch R, Hofbauer H (2014) Wood gas processing to generate pure hydrogen suitable for PEM fuel cells. ACS Sustain Chem Eng 2:2690-2698. https://doi.org/10.1021/sc500436m

3. Kraussler M, Binder M, Hofbauer H (2016) 2250-h long term operation of a water gas shift pilot plant processing tar-rich product gas from an industrial scale dual fluidized bed biomass steam gasification plant. Int J Hydrog Energy 41:6247-6258

4. Rehling B, Hofbauer H, Rauch R, Aichernig C (2011) BioSNGprocess simulation and comparison with first results from a 1-MW demonstration plant. Biomass Convers Biorefinery 1:111-119

5. Thunman H, Seemann M, Berdugo Vilches T, Maric J, Pallares D, Ström H, Berndes G, Knutsson P, Larsson A, Breitholtz C, Santos O (2018) Advanced biofuel production via gasification - lessons learned from 200 man-years of research activity with Chalmers' research gasifier and the GoBiGas demonstration plant. Energy Sci Eng 6:6-34. https://doi.org/10.1002/ese3.188

6. Weber G, Rauch R, Hofbauer H (2015) Influence of ethylene on the formation of mixed alcohols over a $\{\mathrm{M}\} \mathrm{oS} \_2$ catalyst using biomassderived synthesis gas. Biomass Convers Biorefinery 5:85-94

7. The World Bank (2013) The International Cryosphere Climate Initiative. On thin ice-how cutting pollution can slow warming and save lives, Washington DC

8. IPCC (2014, 2014) Climate change 2014: synthesis report. Contribution of working groups I, II and III to the fifth assessment report of the intergovernmental panel on climate change, Geneva

9. Hofbauer H, Rauch R, Loeffler G, Kaiser S, Fercher E, Tremmel H. Six years experience with the FICFB-gasification process. Proc. 12th Eur. Conf. Technol. Exhib. Biomass Energy, Ind. Clim. Prot., Amsterdam: 2002, p. 982-985

10. Devi L, Craje M, Thüne P, Ptasinski KJ, Janssen FJJG (2005) Olivine as tar removal catalyst for biomass gasifiers: catalyst characterization. Appl Catal A Gen 294:68-79. https://doi.org/10.1016/ j.apcata.2005.07.044

11. Öhman M, Nordin A, Skrifvars B-JJ, Backman R, Hupa M (2000) Bed agglomeration characteristics during fluidized bed combustion of biomass fuels. Energy Fuel 14:169-178. https://doi.org/10.1021/ ef990107b

12. Kirnbauer F, Hofbauer H (2011) Investigations on bed material changes in a dual fluidized bed steam gasification plant in Güssing, Austria. Energy and Fuels 25:3793-3798. https://doi. org/10.1021/ef200746c

13. Kaknics J, Michel R, Richard A, Poirier J (2015) High-temperature interactions between molten miscanthus ashes and bed materials in a fluidized-bed gasifier. Energy and Fuels 29:1785-1792. https:// doi.org/10.1021/ef502750t

14. Berdugo Vilches T, Marinkovic J, Seemann MC, Thunman H (2016) Comparing active bed materials in a dual fluidized bed biomass gasifier: olivine, bauxite, quartz-sand and ilmenite. Energy Fuels:acs.energyfuels.6b00327. https://doi.org/10.1021/acs. energyfuels.6b00327

15. Kuba M, He H, Kirnbauer F, Skoglund N, Boström D, Öhman M, Hofbauer H (2016) Mechanism of layer formation on olivine bed particles in industrial-scale dual fluid bed gasification of wood. Energy Fuels 30:7410-7418. https://doi.org/10.1021/acs. energyfuels.6b01522

16. He H, Ji X, Boström D, Backman R, Öhman M (2016) Mechanism of quartz bed particle layer formation in fluidized bed combustion of wood-derived fuels. Energy Fuels 30:2227-2232. https://doi.org/ 10.1021/acs.energyfuels.5b02891

17. Wagner K, Häggström G, Skoglund N, Priscak J, Kuba M, Öhman M, Hofbauer H (2019) Layer formation mechanism of K-feldspar in bubbling fluidized bed combustion of phosphorus-lean and 
phosphorus-rich residual biomass. Appl Energy 248:545-554. https://doi.org/10.1016/j.apenergy.2019.04.112

18. Grimm A, Skoglund N, Boström D, Öhman M (2011) Bed agglomeration characteristics in fluidized quartz bed combustion of phosphorus-rich biomass fuels. Energy and Fuels 25:937-947. https://doi.org/10.1021/ef101451e

19. Pommer L, Öhman M, Boström D, Burvall J, Backman R, Olofsson I, Nordin A (2009) Mechanisms behind the positive effects on bed agglomeration and deposit formation combusting forest residue with peat additives in fluidized beds. Energy and Fuels 23:42454253. https://doi.org/10.1021/ef900146e

20. Konstandopoulos AG (2000) Deposit growth dynamics: particle sticking and scattering phenomena. Powder Technol 109:262 277. https://doi.org/10.1016/S0032-5910(99)00242-9

21. Tranvik AC, Öhman M, Sanati M (2007) Bed material deposition in cyclones of wood fuel fired circulating fluidized beds (CFBs). Energy and Fuels 21:104-109. https://doi.org/10.1021/ef060175f

22. Kirnbauer F, Wilk V, Kitzler H, Kern S, Hofbauer H (2012) The positive effects of bed material coating on tar reduction in a dual fluidized bed gasifier. Fuel 95:553-562. https://doi.org/10.1016/j. fuel.2011.10.066

23. Berdugo Vilches T, Maric J, Knutsson P, Rosenfeld DC, Thunman H, Seemann M (2018) Bed material as a catalyst for char gasification: the case of ash-coated olivine activated by $\mathrm{K}$ and $\mathrm{S}$ addition. Fuel 224:85-93. https://doi.org/10.1016/j.fuel.2018.03.079

24. Kuba M, Havlik F, Kirnbauer F, Hofbauer H (2015) Influence of bed material coatings on the water-gas-shift reaction and steam reforming of toluene as tar model compound of biomass gasification. Biomass Bioenergy 89:40-49. https://doi.org/10.1016/j. biombioe.2015.11.029

25. Kryca J, Prišćák J, Łojewska J, Kuba M, Hofbauer H (2018) Apparent kinetics of the water-gas-shift reaction in biomass gasification using ash-layered olivine as catalyst. Chem Eng J 346:113119. https://doi.org/10.1016/j.cej.2018.04.032
26. Knutsson P, Cantatore V, Seemann M, Tam PL, Panas I (2018) Role of potassium in the enhancement of the catalytic activity of calcium oxide towards tar reduction. Appl Catal B Environ 229:88-95. https://doi.org/10.1016/j.apcatb.2018.02. 002

27. Wagner K, Häggström G, Mauerhofer AM, Kuba M, Skoglund N, Öhman M, Hofbauer H (2019) Layer formation on K-feldspar in fluidized bed combustion and gasification of bark and chicken manure. Biomass Bioenergy 127:105251. https://doi.org/10.1016/j. biombioe.2019.05.020

28. Kuba M, He H, Kirnbauer F, Boström D, Öhman M, Hofbauer H (2015) Deposit build-up and ash behavior in dual fluid bed steam gasification of logging residues in an industrial power plant. Fuel Process Technol 139:33-41. https://doi.org/10.1016/j.fuproc.2015. 08.017

29. Kuba M, Kraft S, Kirnbauer F, Maierhans F, Hofbauer H (2018) Influence of controlled handling of solid inorganic materials and design changes on the product gas quality in dual fluid bed gasification of woody biomass. Appl Energy 210:230-240. https://doi. org/10.1016/j.apenergy.2017.11.028

30. Kraft S, Kuba M, Hofbauer H (2018) The behavior of biomass and char particles in a dual fluidized bed gasification system. Powder Technol 338:887-897. https://doi.org/10.1016/j.powtec.2018.07. 059

31. Rauch R, Bosch K, Hofbauer H, Świerczyński D, Courson C (2006) Comparison of different olivines for biomass steam gasification. Sci Therm Chem Biomass Convers:799-809

32. Kirnbauer F, Hofbauer H (2013) The mechanism of bed material coating in dual fluidized bed biomass steam gasification plants and its impact on plant optimization. Powder Technol 245:94-104

Publisher's Note Springer Nature remains neutral with regard to jurisdictional claims in published maps and institutional affiliations. 